\title{
Impact of atmospheric warming on permafrost degradation and debris flow initiation - a case study from the eastern European Alps
}

\author{
Bodo Damm, Astrid Felderer
}

How to cite:

Abstract:

Kurzfassung:

Keywords:
DAMm, B., Felderer, A. (2013): Impact of atmospheric warming on permafrost degradation and debris flow initiation - a case study from the eastern European Alps. - E\&G Quaternary Science Journal, 62 (2): 136-149. DOI: 10.3285/eg.62.2.05

\begin{abstract}
The present study demonstrates the importance of recent atmospheric warming for the spatial distribution of debris flow initiation in a central alpine area of the Eastern Alps. In particular, permafrost degradation due to increasing mean annual air temperature (MAAT) since the end of the Little Ice Age (LIA) caused mechanical instabilities of sediments and slopes. In the study area, the Rieserferner-Ahrn Nature Park, it can be shown that almost half of the debris flow initiation zones originate in areas with loose rock that were still stabilized by glacier ice and/or permafrost about 150 years ago.

At present, the permafrost area covers $109 \mathrm{~km}^{2}$ in the study area, while it covered $\sim 211 \mathrm{~km}^{2}$ during thermal conditions at the end of the LIA. Since then glacier recession and permafrost degradation exposed extended areas of unconsolidated debris that are uniformly distributed in the Rieserferner-Ahrn Nature Park. In general, present-day debris flows mainly originate from corresponding sediments, where permafrost degraded since the end of the LIA. These sediments are now susceptible to debris flow hazards.

Compared to present conditions the permafrost area would decrease by approximately $72 \%$ by the middle of the 21 st century with regard to an increased air temperature of +1 to $+2 \mathrm{~K}$. Moreover, glaciers widely disappear in this scenario. Ongoing glacier recession and permafrost degradation increase the amount of instable debris as well as the potential of debris flow detachment zones in the future.
\end{abstract}

Der Einfluss der atmosphärischen Erwärmung auf Permafrostdegradation und das Anreißen von Muren - eine Fallstudie aus den Ostalpen

In der vorliegenden Arbeit wird die Bedeutung der Erwärmung der Kryosphäre seit dem Ende der Kleinen Eiszeit (LIA) für die räumliche Verbreitung von Muranrissen in einem zentralalpinen Gebiet der Ostalpen untersucht. Vor dem Hintergrund der atmosphärischen Erwärmung verursachte hier insbesondere die Degradation von Permafrost bodenmechanische Instabilitäten. Im Untersuchungsgebiet, dem Naturpark Rieserferner-Ahrn in Südtirol lässt sich zeigen, dass mehr als die Hälfte der Muranrisse in Lockergesteinen auftreten, unter anderem in Moränen- und Hangschuttablagerungen, die vor rund 150 Jahren noch durch Gletschereis und Permafrost stabilisiert waren.

Derzeit sind rund $109 \mathrm{~km}^{2}$ des Untersuchungsgebietes von Permafrost unterlagert, während unter den thermischen Bedingungen der Kleinen Eiszeit diese Fläche noch rund $211 \mathrm{~km}^{2}$ umfasste. Die seither von Gletscherschwund und/oder Permafrostdegradation betroffenen Areale mit schlecht oder nicht konsolidierten Ablagerungen sind über das untersuchte Gebiet weitgehend gleichmäßig verteilt. Ein Großteil der erfassten Muranrisse tritt in entsprechenden und nun für gefährliche Prozesse disponierten Sedimenten auf.

Unter Berücksichtigung aktueller Klimaszenarien mit einem Anstieg der Lufttemperaturen um +1 bis $+2 \mathrm{~K}$ bis zur Mitte des 21. Jahrhunderts würde sich das von Permafrost unterlagerte Areal im Untersuchungsgebiet um annähernd $72 \%$ gegenüber aktuellen Bedingungen verringern. Gleichzeitig würden die Gletscherflächen weitgehend verschwinden. In Zukunft ist durch anhaltenden Gletscherschwund und Permafrostdegradation daher mit einer Zunahme instabiler Schuttvorkommen und einer räumlichen Zunahme von Muranrissen und Murprozessen zu rechnen.

atmospheric warming, climate change, glacier recession, permafrost degradation, natural hazards, debris flow initiation, Little Ice Age, European Alps

Addresses of authors: B. Damm, University of Vechta, ISPA, Universitätsstraße 5, D-49377 Vechta, Germany. E-Mail: bdamm@ispa.uni-vechta.de A. Felderer, Umweltbundesamt Wien, Umweltfolgenabschätzung \& Klimawandel, Spittelauer Lände 5, A-1090 Wien, Austria.

\section{Introduction}

Glacier ice and permafrost ice react sensitive to climate variability in the European Alps (cf. BENISTON et al. 1997, DAVIES et al. 2001, ArEnson 2003, DAMM \& LANGER 2006, HARRIS et al. 2009). Since the end of the "Little Ice Age" (LIA), about 150 years ago, the temperature increase especially af- fected the mountain cryosphere (e.g. LEWIN \& WARBURTON 1994, HARris et al. 2003, Stötter et al. 2003, HAEBerLi $\mho$ GrUBER 2009). High-mountain environments are presumed to response to atmospheric warming with glacier recession, increased permafrost temperatures and increased slope instabilities (STOFFEL \& Huggel 2012). In turn, these changes affect present and future natural hazards (cf. HAEBERLI et 


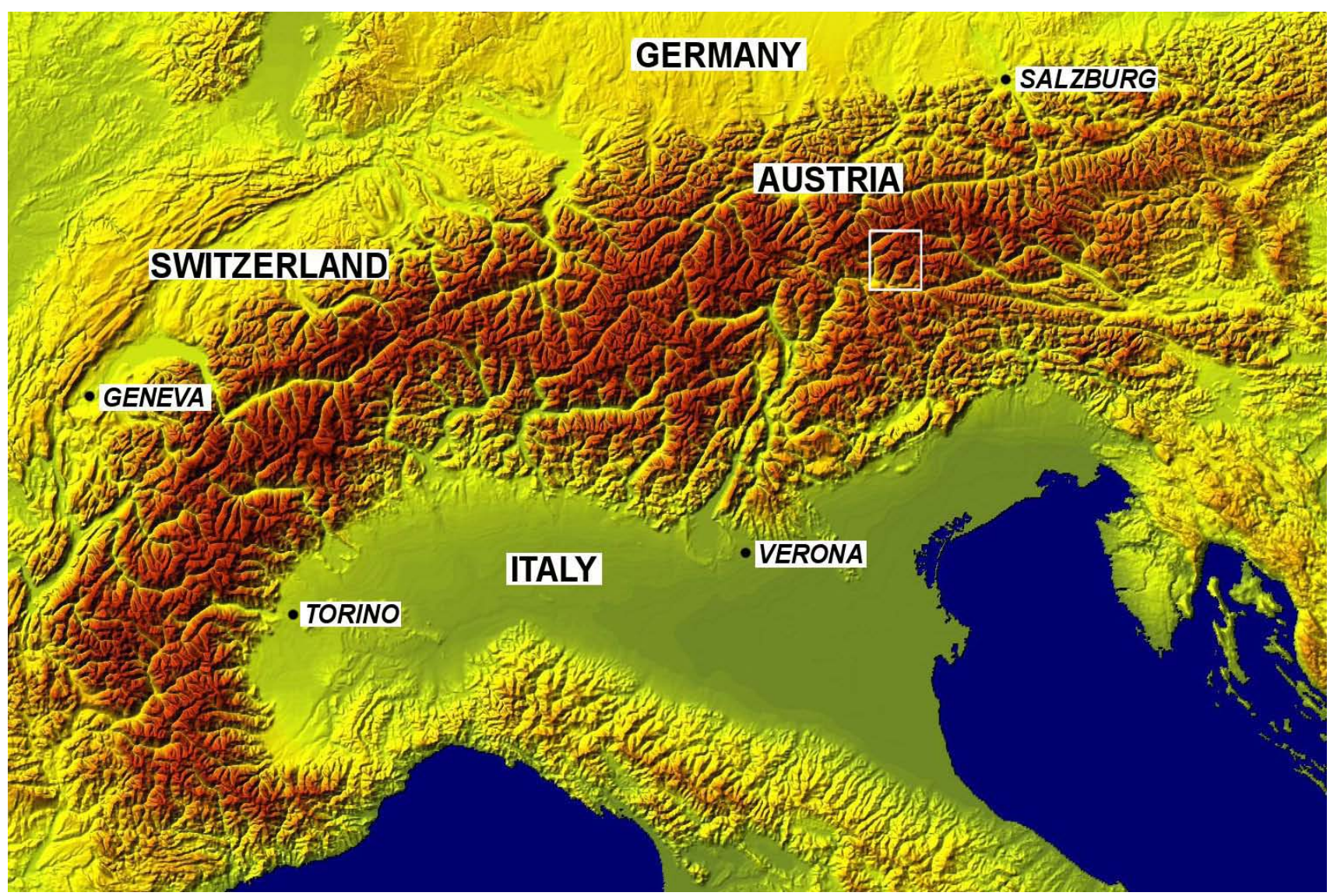

Fig. 1: European Alps with the location of the study area Rieserferner-Ahrn Nature Park (box) and the adjacent areas in South Tyrol (Italy).

Abb. 1: Der Alpenraum mit der Lage des Untersuchungsgebietes Naturpark Rieserferner-Ahrn (Kasten) und angrenzenden Gebieten in Südtirol (Italien).

al. 1999, DAviEs et al. 2001, HARris et al., 2001, GrUBER et al. 2004, Harris 2005, Fischer et al. 2006, DAmM \& Felderer 2008, Pröbstl \& DAmm 2009, KeILER et al. 2010).

The glacier retreat since the end of the LIA is well documented in the European Alps (e.g. DAmм 1998, LAMBrecht \& KuHn 2007, Zemp et al. 2007, WinkLer 2009, WinkLER et al. 2010). In contrast, knowledge on the occurrence and distribution of permafrost and its spatiotemporal change during the last 150 years is comparatively scarce (cf. VONDER MueHLL et al. 2007, MAIR et al. 2008). Early investigations estimated an increase of the mean annual air temperature (MAAT) of about +1 to $+2 \mathrm{~K}$ since the end of the LIA in permafrost areas of the European Alps (cf. Kunn 1990, Patzelt \& Aellen 1990, HAEBERLi 1992). Thus, based on a thermal gradient of $0.5-0.6 \mathrm{~K} / 100 \mathrm{~m}$, the lower limit of permafrost increased by 150-300 $\mathrm{m}$ during the last 150 years (e.g. DAMm \& LANGER 2006, see also HAEBerli 1999). Similarly, the prognosticated increase of air temperature of +1 to $+2 \mathrm{~K}$ in the Eastern Alps by the middle of the $21^{\text {st }}$ century (cf. MATUlLA et al. 2002, MATULLA 2005) may lead to an additional rise of equilibrium line altitudes (ELA) of alpine glaciers of approximately 150-350 $\mathrm{m}$ and a further increase of the lower limits of permafrost of 200-400 m. According to this scenario, numerous glaciers within the eastern Alps would disappear and permafrost diminish to the highest summits. Both processes would affect the stability of mountain slopes and walls (e.g. DAviEs et al. 2001, ZEMP et al. 2006, 2007).

The thawing of mountain permafrost is expected to significantly affect geotechnical properties of perennially frozen and unconsolidated debris and may result in a regional increase of debris flow frequency and magnitude (cf. ZIMmERMANn et al. 1997, Harris 2005, Stoffel \& Huggel 2012). Both, the complete melting of the permafrost body and the lowering of the thaw front within permafrost may reduce the shear strength of debris. Instabilities appear most likely to occur in areas near the lower limit of contemporary permafrost distribution, where permafrost bodies are thin and have temperatures close to $0^{\circ} \mathrm{C}$ (HAEBerLi 1992). Successive failure of the unconsolidated debris destabilized in such a manner can be triggered by the oversaturation of the active layer or debris above water-impermeable rock (e.g. DAmM et al. 2012, SANDMEIER et al. 2012) or by the release of fine grained material formerly fixed in the ice matrix (SATTLER et al. 2011). However, the mechanisms of permafrost degradation and related slope stability are rather complex and many aspects and links remain uncertain to date (STOFFEL \& HugGEL 2012).

The theoretical relation between permafrost degradation in non-creeping slope material and the initiation or increase of debris flow activity has hardly been verified. Field studies of debris flow-triggering mechanisms on thawing slopes remain a challenge given the difficulties to predict where and when slope instabilities occurs (cf. HARrIs 2005). Still, there are some observations of large numbers of debris flows originating in areas presumed to be at the margin of contemporary permafrost distribution supporting the hypothesis mentioned above (e.g. Zimmermann \& HaEberli 1992, Stötter et al. 2003, SATtLer et al. 2011). However, these studies are based on comparatively small study areas and/or short time-frames.

The present study aims to identify and to prove the rela- 
tion among atmospheric warming, the spatial variability of glaciers and permafrost and the spatial distribution of debris flows in the study area during the last 150 years. Furthermore, the study aims to predict future spatial development of glacier and permafrost distribution in relation to debris flows as hazardous geomorphic processes using a GIS-based modelling approach. Climatic basis of the scenario is an expected increase of air temperature by $+1.5 \mathrm{~K}$ until the middle of the $21^{\text {st }}$ century (cf. MATUlLA et al. 2002, Matulla 2005, IPCC 2007b). Thus, for the first time this study provides data of the development of hazard potential from debris flow processes in the eastern Alps that exceed the spatial dimension of a catchment area (cf. STÖTTER et al. 2003, KNeisel et al. 2007, DAmm \& Felderer 2008).

\section{Regional setting}

The study area (fig. 1) extends to $450 \mathrm{~km}^{2}$ and covers the Rieserferner-Ahrn Nature Park in South Tyrol (Italy) and adjacent areas of the Hohe Tauern National Park (Austria). It comprises the Rieserferner and Durreck Mountains, parts of the Zillertaler Alps south flank, and the outer west parts of the Venediger Mountains. Highest peaks in the study area reach up to $3,500 \mathrm{~m}$ a.s.l.

The central parts of the study area are dominated by granodiorite and tonalite bedrock. Additionally, pegmatite, paragneiss, mica schist, and orthogneiss are present. Large areas in the upper valleys are covered by poorly consolidated or unconsolidated sediments, particularly debris cones, talus, till and slide masses (SANDMEIER et al. 2012). These sediments of Late Glacial and Holocene age can reach thickness of several decametres (DAMm 1996). In general, most of the material is not or only sparsely vegetated. Erosion and debris flow processes can be frequently observed.

In general, the study area is characterized by comparably continental climate. Mean annual precipitation varies throughout the study area and is highest in the northern part of the Rieserferner-Ahrn Nature Park with up to $1030 \mathrm{~mm}$ (meteorological station of Prettau, period of 1981-2000), as this region is close to the central Alpine divide. Main precipitation period is the summer with frequent convective rainfall.

The thermal gradient shows significant seasonal variations and ranges from $0.7^{\circ} \mathrm{C} / 100 \mathrm{~m}$ (summer) to $0.35^{\circ} \mathrm{C} / 100 \mathrm{~m}$ (winter) based on data of nine meteorological stations between $821 \mathrm{~m}$ a.s.l. and $3105 \mathrm{~m}$ a.s.l. for the period 1994-2004 (tab. 1, cf. DAMM \& LANGER 2006). Using a mean thermal gradient of $0.57 \mathrm{~K} / 100 \mathrm{~m}$ (tab. 2), the calculated $0{ }^{\circ} \mathrm{C}$-isotherm is at $2323 \mathrm{~m}$ a.s.l.

Since the end of the Little Ice Age about AD 1860 the glacier area decreased by 50 to $65 \%$ in the Rieserferner-Ahrn Nature Park. The loss of glacier surface was marginally above-average compared to surrounding mountain groups of the Eastern Alps (cf. DAmm 1998, RöSEN 2005). Strong glacier recession was recorded during the last three decades when the ELA partially rose up to $3100 \mathrm{~m}$ a.s.l. within the study area. Significant mass losses occurred during this period, which were related to the decrease of the Accumulation Area Ratios (AAR), for example at the Western Rieser glacier (cf. Secchieri \& VAlentini 1985, Autonome Provinz Bozen 2010, 2011).

\begin{tabular}{|c|c|c|}
\hline Meteorological station & Coordinate & Altitude [m a.s.I.] \\
\hline Bruneck & $11^{\circ} 55^{\prime} 53^{\prime \prime} \mathrm{E} / 46^{\circ} 48^{\prime} 16^{\prime \prime} \mathrm{N}$ & 821 \\
\hline Mühlen & $11^{\circ} 56^{\prime} 25^{\prime \prime} \mathrm{E} / 46^{\circ} 54^{\prime} 06^{\prime \prime} \mathrm{N}$ & 870 \\
\hline Steinhaus & $11^{\circ} 58^{\prime} 34^{\prime \prime} \mathrm{E} / 46^{\circ} 59^{\prime} 46^{\prime \prime} \mathrm{N}$ & 1080 \\
\hline Antholz - Mittertal & $12^{\circ} 06^{\prime} 55^{\prime \prime} \mathrm{E} / 46^{\circ} 51^{\prime} 30^{\prime \prime} \mathrm{N}$ & 1236 \\
\hline Antholz - Obertal & $12^{\circ} 06^{\prime} 55^{\prime \prime} \mathrm{E} / 46^{\circ} 52^{\prime} 14^{\prime \prime} \mathrm{N}$ & 1320 \\
\hline Prettau & $12^{\circ} 05^{\prime} 51^{\prime \prime} \mathrm{E} / 47^{\circ} 02^{\prime} 13^{\prime \prime} \mathrm{N}$ & 1449 \\
\hline Rein in Taufers & $12^{\circ} 04^{\prime} 34^{\prime \prime} \mathrm{E} / 46^{\circ} 56^{\prime} 46^{\prime \prime} \mathrm{N}$ & 1600 \\
\hline Prettau - Merbalm & $12^{\circ} 07^{\prime} 21^{\prime \prime} \mathrm{E} / 47^{\circ} 02^{\prime} 11^{\prime \prime} \mathrm{N}$ & 2002 \\
\hline Prettau - Lengspitze & $12^{\circ} 07^{\prime} 52^{\prime \prime} \mathrm{E} / 47^{\circ} 00^{\prime} 57^{\prime \prime} \mathrm{N}$ & 3105 \\
\hline
\end{tabular}

Tab. 1: Position and altitude of meteorological stations used for the calculation of thermal gradients of monthly and annual air temperature in the Rieserferner-Ahrn Nature Park and adjacent areas (source: Autonomous Province of Bozen-South Tyrol - Hydrographic Office).

Tab. 1: Lage und Höhe von Wetterstationen zur Berechnung thermischer Gradienten der monatlichen und jährlichen Luftemperaturen im Naturpark Rieserferner-Ahrn und angrenzenden Gebieten (Quelle: Autonome Provinz Bozen-Südtirol - Hydrographisches Amt).

Tab. 2: Thermal gradients of monthly and annual air temperature and $0^{\circ} \mathrm{C}$-isotherm based on data of nine meteorological stations in the Rieserferner-Ahrn Nature Park and adjacent areas for the period 1994-2004 according to DAMM \& LANGER (2006).

Tab. 2: Thermische Gradienten der monatlichen und jährlichen Lufttemperatur sowie $0^{\circ} \mathrm{C}$-Isotherme auf der Grundlage von neun Wetterstationen im Naturpark Rieserferner-Ahrn und angrenzenden Gebieten für den Zeitraum 1994-2004 nach DAMM \& LANGER (2006).

\begin{tabular}{|c|c|c|c|c|c|c|c|c|c|c|c|c|c|}
\hline Month & Jan & Feb & Mar & Apr & May & Jun & Jul & Aug & Sep & Oct & Nov & Dec & Year \\
\hline $\begin{array}{c}\text { Thermal gradient } \\
{[\mathrm{K} / 100 \mathrm{~m}]}\end{array}$ & 0,36 & 0,51 & 0,64 & 0,70 & 0,70 & 0,68 & 0,70 & 0,62 & 0,59 & 0,53 & 0,48 & 0,35 & 0,57 \\
\hline $\begin{array}{c}0^{\circ} \mathrm{C}-\text { Isotherm } \\
\text { [m a.s.l.] }\end{array}$ & -34 & 917 & 1633 & 2009 & 2801 & 3356 & 3473 & 3857 & 3072 & 2536 & 1439 & 280 & 2323 \\
\hline
\end{tabular}




\section{Methods and data sets}

\section{Ground survey}

Field work comprises the identification, mapping and assessment of geomorphological, hydrological and physical permafrost indicators, such as active and intact rock glaciers, frozen talus, frozen till and perennial snow patches, as well as measurements of basal temperature of snow cover (BTS) and temperature of meltwater from permafrost springs (DAMM \& LANGER 2006).

Rock glaciers (fig. 2) and frozen talus are characterized by flow structures and were mapped, similar as snow patches, by use of aerial photographs in combination with ground-truth data. In contrast, frozen till and ice saturated talus (fig. 3) were identified by field survey. A total of 30 rock glaciers that still containing ice were recorded (cf. DAMM 1996, 1999), indicating a mean lower limit at $2600 \mathrm{~m}$ a.s.l. In addition, ice saturated talus and till was mapped at 69 locations in altitudes between $2240 \mathrm{~m}$ a.s.l. and $3160 \mathrm{~m}$ a.s.l.

Ground surface temperatures (GST) were logged over a 5-years period from 2003 to 2008 using temperature loggers with a resolution of $\pm 0.2 \mathrm{~K}$. The ONSET HOBO loggers were positioned at 32 measuring points in altitudes of 2434 to $3340 \mathrm{~m}$ a.s.l. on different locations of rock glaciers, frozen talus, frozen till as well as in the surroundings of perennial snow patches. The recorded temperatures of $-2.9^{\circ} \mathrm{C}$ to $-9.5^{\circ} \mathrm{C}$ on south oriented slopes (2760 to $3040 \mathrm{~m}$ a.s.l.) and $-2.9^{\circ} \mathrm{C}$ to $-7.9^{\circ} \mathrm{C}$ on north oriented slopes (2560 to $2680 \mathrm{~m}$ a.s.l.) both characterize the long-term thermal conditions in permafrost areas during winter period and below snow cover. The basal temperature of snow cover (e.g. HAEBERLI 1973, ISHIKAWA \& HIRAKAWA 2000) was detected with a transportable BTS sensor in February 2006 in the proglacial area of the Rieserferner glacier and on the glacier tongue. On the basis of ground surface temperatures and BTS the lower limit of discontinuous permafrost is expected to be at 2530 $\mathrm{m}$ a.s.l. in north orientation and at $2730 \mathrm{~m}$ a.s.l. in south orientation, indicating for this limit mean annual air temperatures (MAAT) of $-1.5^{\circ} \mathrm{C}$ and $-2.6^{\circ} \mathrm{C}$ respectively (fig. 4 ).

\section{Use of analogues and digital spatial data}

Ground survey and mapping were carried out using aerial photographs of 1997 and 1999 with a resolution of 4 m, digital

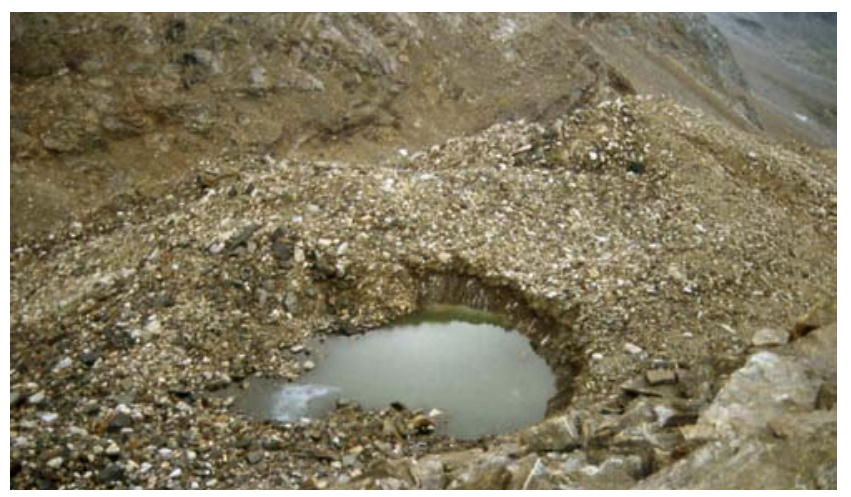

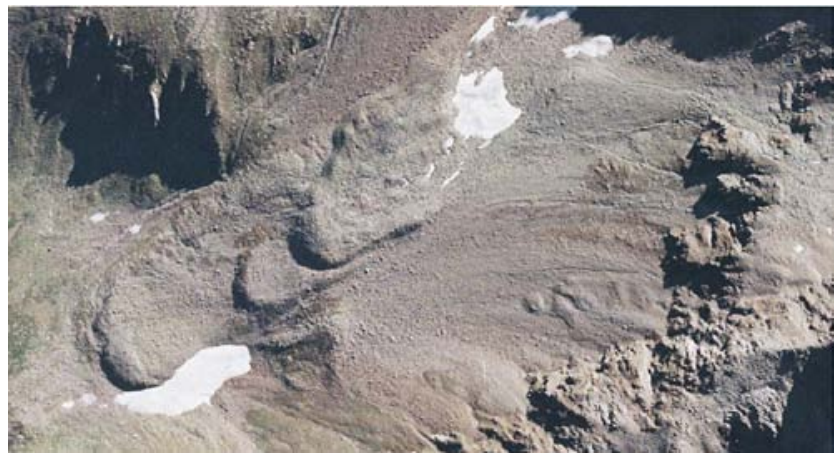

Fig. 2: Rock glaciers at 2500-2650 $\mathrm{m}$ a.s.l. in the Rieserferner-Ahrn Nature Park. These geomorphologic phenomena are characterized by flow structures and were mapped by use of aerial photographs and field survey (source: orthophoto of the Autonomous Province of Bozen).

Abb. 2: Durch Fließstrukturen charakterisierter Blockgletscher in 2500-2650 m ü.M. im Naturpark Rieserferner-Ahrn. Blockgletscher wurden für die vorliegende Arbeit auf der Grundlage von Orthophotos und Feldarbeiten kartiert (Quelle: Orthophoto der Autonomen Provinz Bozen-Südtirol).

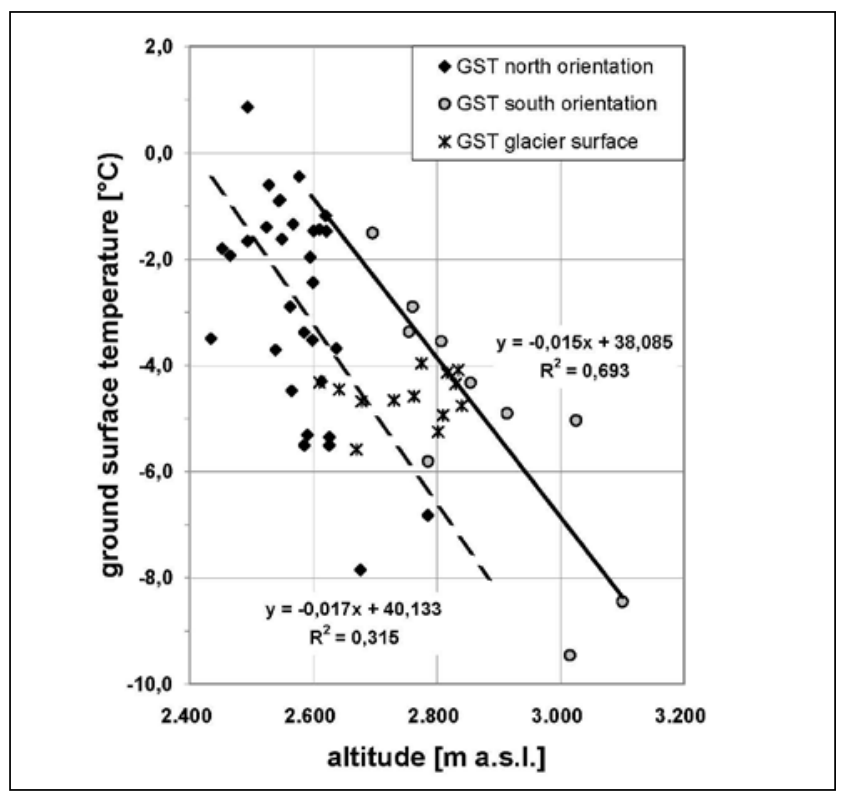

Fig. 4: Relationship between ground surface temperature and altitude derived from temperature logging and BTS measurements in the RieserfernerAhrn Nature Park (modified from DAMM \& LANGER 2006).

Abb. 4: Beziehung zwischen BTS-Werten aus Temperaturlogger- und Sondenmessungen sowie der Geländehöhe der Messpunkte in unterschiedlichen Expositionen im Naturpark Rieserferner-Ahrn (verändert aus DAMM \& LANGER 2006).

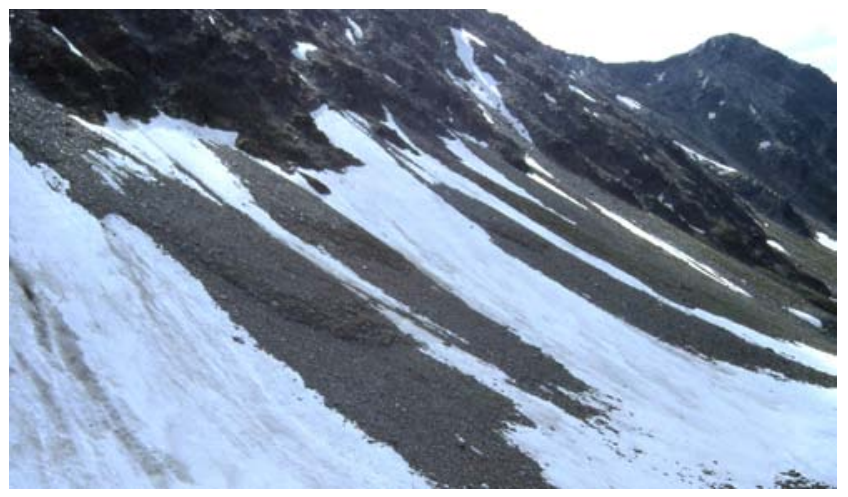

Fig. 3: Permafrost degradation in frozen till of a LIA terminal moraine at $2700 \mathrm{~m}$ a.s.l. (left hand) and ice saturated talus at $2600 \mathrm{~m}$ a.s.l. in the Rieserferner-Ahrn Nature Park (right hand) (photographs: B. Damm).

Abb. 3: Degradation von Permafrost in einer Stirnmoräne des neuzeitlichen Gletscherhochstandes um 1850 in rund $2700 \mathrm{~m}$ Höhe (links) und eisgesättigter Hangschutt in 2600 m Höhe im Naturpark Rieserferner-Ahrn (rechts) (Aufnahmen: B. Damm). 
orthophotos with a resolution of $1 \mathrm{~m}$, land cover maps and a digital elevation model (DEM 20x20 m grid) allocated by the government of the Autonomous Province of South Tyrol. Land cover maps are based on aerial photo interpretation and were available in a scale of 1:10,000 (ZANVETTOR et al. 2006).

\section{Mapping of debris flow initiation areas}

Debris flow initiation areas were identified using digital orthofotographs of the summer/autumn 1999 with a resolution of one meter and mapped as point data within ArcGIS 9.1 using the DEM of the Autonomous Province of South Tyrol. In general, initiation areas were defined as areas on which material is released due to erosion or land slide and from which the material is subsequently transported by flow processes in channelized and open-slope debris flows. The mapped debris flow source areas were classified based on spatial distribution, elevation and slope and intersected with the grid information of the DEM.

\section{Assessment and simulation of permafrost distribution and glacier recession}

The calculation of the present mountain permafrost distribution is based on the spatial distribution of perennial snow patches, which can be detected easily with remote sensing techniques. Widespread remnants of snow cover at the end of the late summer suggest low or negative ground temperatures underneath. Hence, the frequent occurrence of perennial snow patches may imply the existence of permafrost in the immediate vicinity (cf. FURRER \& FITZE 1970, RoLSHOVEN 1982).

The spatial distribution of 3000 perennial snow patches (total area: ca. 390 ha) between $2100 \mathrm{~m}$ a.s.l. and $3450 \mathrm{~m}$ a.s.l. was proved and mapped using aerial photographs of 1985, 1997, and 1999. Taking topography, terrain orientation and altitude into account, the assessment and simulation of permafrost distribution was operated by CRYOSNOW (cf. DAMM \& LANGer 2006, LANGer \& DAMM 2008). CRYOSNOW represents a statistical approach for the simulation of mountain permafrost and identifies to what extend the spatial frequency of perennial snow patches correspond to the spatial distribution of permafrost. In addition to the analysis of snow patches, the simulation also tested the measured and recorded characteristics of hydrological, physical and geomorphologic permafrost indicators (see above). Measured and approximated permafrost areas are significantly correlated. Thus, these parameters allow the determination of the lower limit of discontinuous permafrost areas in the study area (cf. DAMM \& LANGER 2006).

Data about the recession of the glaciers in the Rieserferner-Ahrn Nature Park were derived from studies of DAMm (1998), RöSEN (2005) and supplementary analysis of aerial photographs and orthofoto images. Assuming a future increase of air temperature (MATULLA et al. 2002, MATULLA 2005, see below), the ELA of glaciers rises, based on a thermal gradient of $0.66^{\circ} \mathrm{C}$ per $100 \mathrm{~m}$ related to summer temperatures.

\section{Analysis and prediction of hazard susceptibility in re- lation to a variable cryosphere}

The distribution of permafrost areas and glacier extent for colder and warmer climatic conditions in the past and fu-

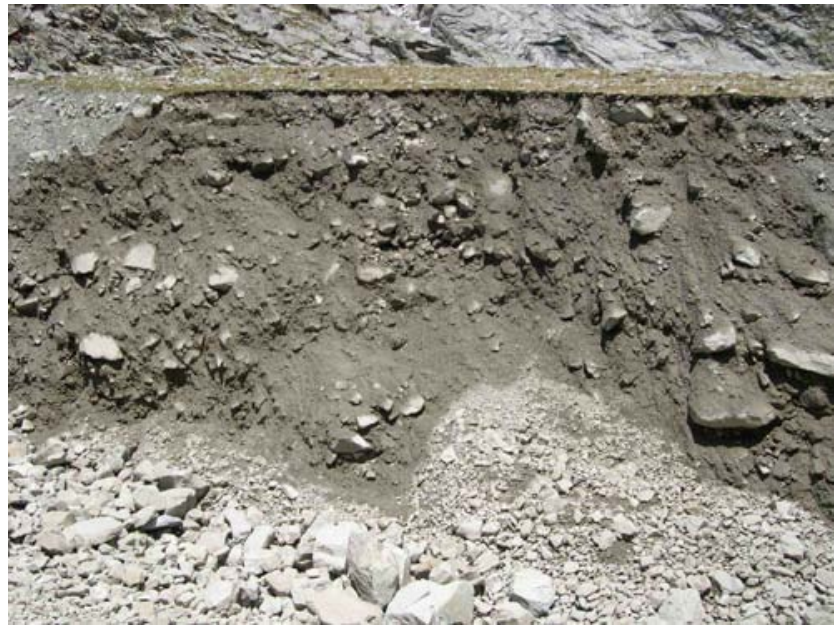

Fig. 5: $10 \mathrm{~m}$ thick section of a debris flow gully in the Klammbach catchment area. Extended surface area is covered by talus, debris cones and till deposits of Late Glacial and Holocene glaciations (photograph: B. Damm).

Abb. 5: Aufschluss in einem rund 10 Meter hohen Anriss einer Mure im Klammbach-Einzugsgebiet. Ausgedehnte Flächen im Umfeld sind von Hangschutt, Schuttkegeln und Moränen spät- und postglazialer Gletscher bedeckt (Aufnahme: B. Damm).

ture was calculated to analyse and predict hazard susceptibility in relation to a variable cryosphere (cf. DAMM \& LANGER 2006). Referring to this, the end of the LIA is supposed to represent an environmental status of increased geomorphologic stability with more extended permafrost and glacier areas compared to the present situation. In contrast, the future environmental status with an expected increase of air temperature by $1.5 \mathrm{~K}$ until the middle of the $21^{\text {st }}$ century (cf. MATUlla et al. 2002, MATULLA 2005, IPCC 2007a, 2007b) is presumed to change to more unstable geomorphologic conditions with reduced permafrost area and shrunken glaciers compared to the current state. Thermally controlled permafrost extent is linked to the variability of the lower permafrost limit and was calculated using a thermal gradient of $0.57 \mathrm{~K}$ per $100 \mathrm{~m}$ in the study area (for general discussion see ISHIKAWA \& HIRAKAWA 2000, LEWKOWICZ \& EDNIE 2004).

Erosion surfaces and detachment zones of debris flows predominantly occur in unconsolidated debris bare of vegetation in the study area. Hence, current areas with related sediments and absent vegetation cover were located from land cover maps and intersected with areas of permafrost degradation derived from permafrost and glacier modelling (cf. DAMM \& LANGER 2006) to identify areas that would be exposed to debris flow processes under warmer climate conditions.

\section{Results \\ 4.1 Cryosphere-hazard-interactions: The Klammbach example}

The Klammbach is a tributary stream of the Antholz creek and located in the south-eastern part of the Rieserferner Mountains (see fig. 8). The south facing drainage basin comprises an area of $6.5 \mathrm{~km}^{2}$. Altitudes reach from $1,310 \mathrm{~m}$ to $3,270 \mathrm{~m}$ a.s.l. along a horizontal distance of $3,000 \mathrm{~m}$. The catchment area of the Klammbach is composed of plutonic rock of the Rieserferner-Tonalite. Extended surface area is 

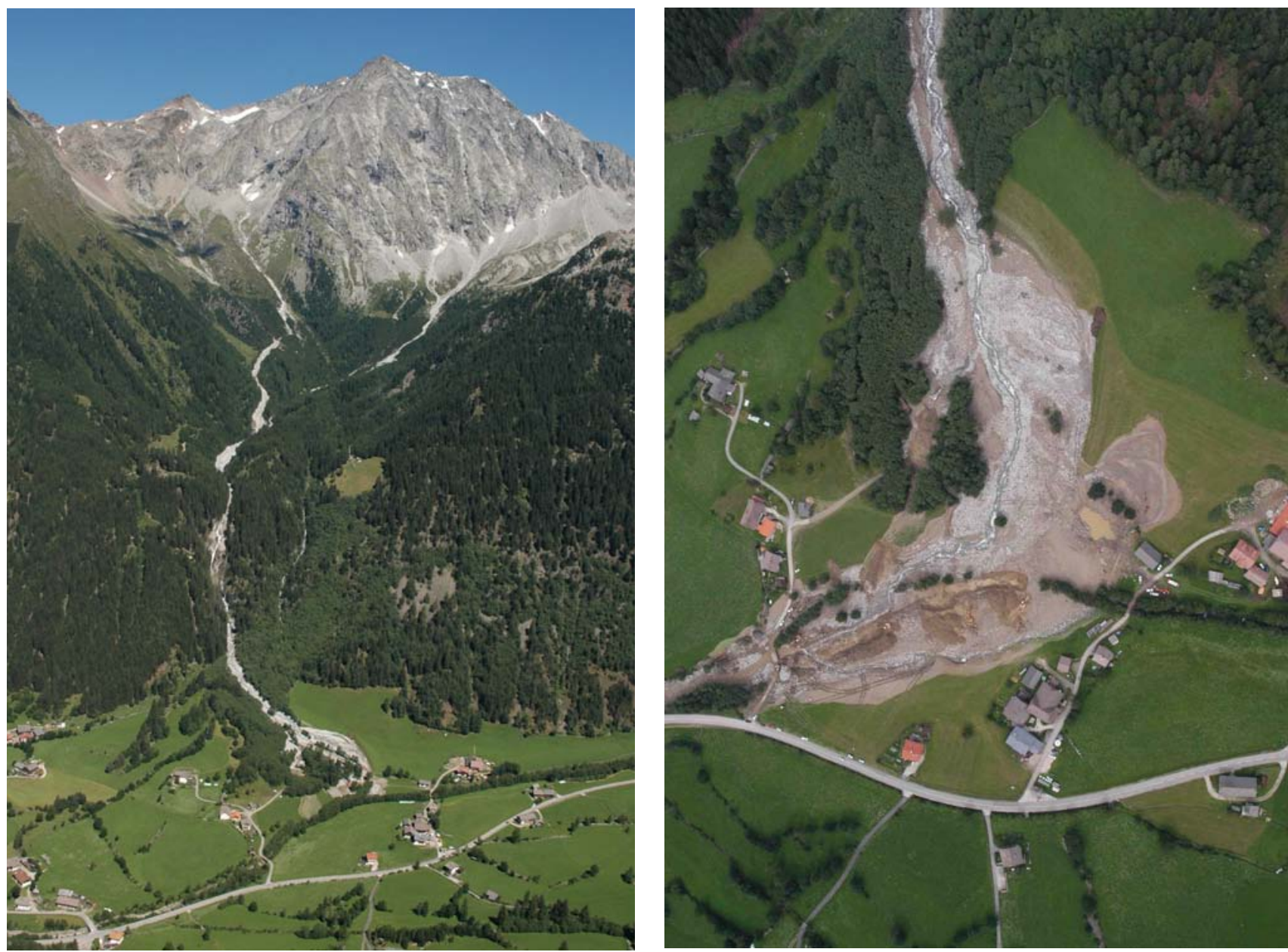

Fig. 6: Klammbach catchment area and main debris flow channel (left-hand photo) and extent of the August 2005-debris flow deposits in Antholz-Mittertal village (right-hand photo) (source: Autonomous Province of Bozen, flood protection office).

Abb. 6: Einzugsgebiet des Klammbachs mit dem zentralen Murgraben (links) und Ausdehnung der Murablagerungen vom August 2005 in Antholz-Mittertal (rechts) (Quelle: Autonome Provinz Bozen-Südtirol, Amt für Wasserschutzbauten).

covered by talus, debris cones and till deposits of Late Glacial and Holocene age (fig. 5). In general, in the upper parts of the Klammbach basin, in particular above the timberline, this material is poorly consolidated and sparsely covered by vegetation.

Several debris flows in the past were supplied from the above-mentioned debris sources. In order to evaluate the sediment characteristics in the Klammbach catchment, different sediment bodies were sampled and analysed concerning their particle size distribution. Grain size distribution was analysed from till of moraine bodies, talus of debris cones and frost debris of an ancient rock glacier (cf. tab. 3). Five samples were taken from debris flow initiation areas and another three samples from fluvial reworked sediments (cf. SANDMEIER et al. 2012). In general, sampling was undertaken at natural cuts in the proximity of debris flow gullies and deposits. Particle size of the sediment was established according to DIN 18123 by wet-sieving using the required mesh width (DIN 18123).

Analyses result in contents of $37 \%$ to $76 \%$ of coarse grain fraction. Fine grain fraction contents high percentage of Sand (70-95\%) and partly of silt (4-27\%), the percentage of clay $(0.3-2 \%)$, in contrast, is low (cf. tab. 3). The different sediments show substantial similarity in their composition and the grain size distribution of samples from debris flow initiation areas is highly similar to samples from debris cones or the rock glacier. According to grain size distribution (BONNET-STAUB 1999), existing proportion of fine and coarse grain (IVERSON 2005) and weak consolidation these sediments are potential sources for debris flows and have to be considered to be controlling factors of these processes (cf. ZnAMENSKY \& GRAMANI 2000, REMAÎTRE et al. 2005).

In summer 2005 a series of three debris flows occurred in the Klammbach gully. In total, about $140,000 \mathrm{~m}^{3}$ of debris was deposited on the alluvial cone in Antholz-Mittertal village (fig. 6). Agricultural area was inundated and the Antholz creek was dammed and displaced (DAMм 2005). Runoff events and the successive two debris flows in July 2005 were triggered by comparatively low rainfall intensities of 0.5 to $3 \mathrm{~mm}$ per minute, which were measured in the upper part of the drainage basin. In contrast, torrential rainfall of $30 \mathrm{~mm}$ during 60 minutes on August $1^{\text {st }} 2005$ triggered the third debris flow with a total volume of about $100,000 \mathrm{~m}^{3}$ (cf. SANDMEIER et al. 2012). This major event originated from a steep debris cone, sparsely covered by vegetation and located below rock flanks and, on the base of ground survey, debris-covered dead ice. The latter are relics of a glacier that melted continuously during the last 80 years. Overland flow from bedrock and dead ice was rapidly conducted into the sediment. Due to several former but smaller events (e.g. 
Tab. 3: Grain size distribution of different sediments in the Klammbach basin (modified from SANDMEIER et al. 2012). *: sample originates from debris flow initiation area. +: sample originates from fluvial reworked sediment.

Tab. 3: Korngrößenverteilung unterschiedlicher Sedimente im Einzugsgebiet des Klammbachs (verändert nach SANDMEIER et al. 2012). *: Probe aus Muranrissbereich. +: Probe aus fluvial umgelagertem Sediment.

\begin{tabular}{|c|c|c|c|c|c|c|c|c|c|c|c|c|}
\hline $\begin{array}{c}\text { Source / } \\
\text { Grain size class }[\mathrm{mm}]\end{array}$ & 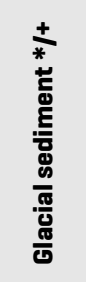 & 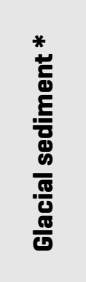 & 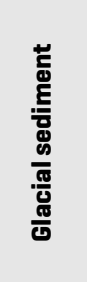 & 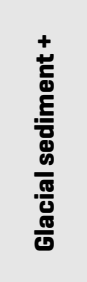 & 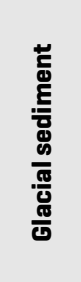 & 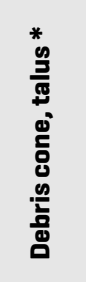 & 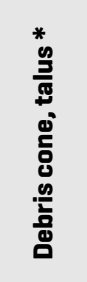 & 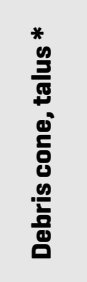 & 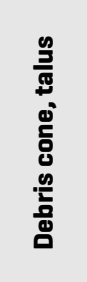 & 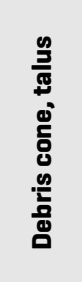 & 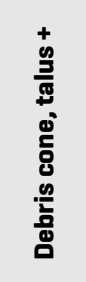 & 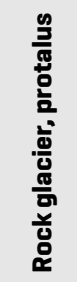 \\
\hline Coarse grain [ $>$ 2] & 47.35 & 72.28 & 52.62 & 36.71 & 62.55 & 67.10 & 55.79 & 53.72 & 53.45 & 75.79 & 56.75 & 55.26 \\
\hline Fine grain $[<2]$ & 52.65 & 27.72 & 47.38 & 63.26 & 37.45 & 32.90 & 44.21 & 46.28 & 46.55 & 24.21 & 43.25 & 44.74 \\
\hline Sand $[0,02-1]$ & 79.59 & 71.61 & 84.14 & 82.84 & 87.08 & 74.23 & 83.55 & 83.92 & 85.57 & 95.30 & 69.87 & 77.70 \\
\hline Silt [0,002-0,02] & 18.54 & 26.55 & 15.10 & 15.83 & 12.00 & 23.74 & 14.99 & 13.07 & 13.73 & 4.41 & 27.20 & 20.32 \\
\hline Clay [<0,002] & 1.88 & 1.84 & 0.76 & 1.33 & 0.92 & 2.03 & 1.46 & 3.01 & 0.70 & 0.29 & 2.93 & 1.98 \\
\hline
\end{tabular}

1882, 1947, 1979) the Klammbach drainage system was already known to be an active debris-flow system (АмT FÜR WASSERSCHUTZBAUTEN 2005). Hence, a storage basin with total retention capacity of $100,000 \mathrm{~m}^{3}$ was constructed on the alluvial cone as a response to the 2005-events.

The following parameters favoured and/or triggered runoff and debris flow processes in particular (АMT FÜR WASSERSCHUTZBAUTEN 2005, DAMM, 2005, 2008):

- On the base of ground survey, extended areas of low or not consolidated talus and till deposits occur in the sparse or not vegetated areas above 2,200 $\mathrm{m}$ a.s.l. They enclose an area of about $25 \%$ of the total drainage basin $\left(6.5 \mathrm{~km}^{2}\right)$.

- The source area of the August-2005-debris-flow was located in a more than $10 \mathrm{~m}$ thick talus cone in contact to bedrock. As result of the GIS-based simulations, this area was most likely underlain with permafrost and stable related to soil-mechanics until the middle of the $19^{\text {th }}$ century. Ground survey indicates that meanwhile permafrost has completely melted.

- Since 1940 mean annual air temperature rose by $1 \mathrm{~K}$ in the Antholz valley (meteorological station of AntholzMittertal). The increase of MAAT caused a rise of the lower permafrost limit of most likely $100-180 \mathrm{~m}$ in the Klammbach drainage basin, using a mean thermal gradient of $0.57 \mathrm{~K} / 100 \mathrm{~m}$.

- Terrain surface properties controlled overland flow. The existence of extended debris covered dead ice without water retention capacity and steeply sloping rock flanks (approx. $60^{\circ}$ ) may have intensified runoff quantity and velocity in the rainfall area. Field study subsequent to the event indicates that runoff infiltrated into the talus cone and increased the soil water pressure.

On the base of ground survey and permafrost modelling, the debris flow processes in the Klammbach basin supposed to be substantially controlled by permafrost degradation in the study area. The detachment area of the main debris flow mentioned above is south exposed and located at an altitude of 2,600 $\mathrm{m}$ a.s.l. Until a few decades ago mountain permafrost still occurred in altitudes and expositions like these throughout the Rieserferner-Ahrn Nature Park (e.g. DAMM \& LANGER 2006).

The degradation of permafrost due to the increase of MAAT caused soil mechanical instabilities of sediments and slopes. Similar to the Klammbach example, our study during the last two decades could frequently verify cryosphere-hazard-interactions in other areas of the Rieserferner-Ahrn Natural Park and the surroundings. This information is recorded in the natural hazard database for the study area and partly in the ED-30 hazard database of the South Tyrol state (ZISCHG et al. 2007).

\subsection{Thermally-controlled development of the cryosphere in the Rieserferner-Ahrn Nature Park}

\section{Development of glaciation}

The glacier retreat since the end of the LIA is comparably well documented in the Rieserferner-Ahrn Nature Park. The glacier surface decreased by $50 \%$ in the Rieserferner Mountains and by $65 \%$ in the upper Ahrntal Mountains over the past 150 years (DAMM 1998, RöSEN 2005). In general a reduction of glacier area is observed for all glaciers of the eastern European Alps since the end of the LIA (ZEMP et al. 2007) however it was slightly above-average in the study area compared to other mountain ranges. Glacier volume in total decreased by $70 \%$ in the Rieserferner-Ahrn Nature Park, even though changes of individual glaciers show a wide variability, depending on their size, physiographic setting and altitude (cf. LAMBRECHT \& KUHN 2007). For this reason, maximum losses generally occurred in ablation zones, but numerous small glaciers completely disappeared.

At present glaciers of the Rieserferner-Ahrn Nature Park are retreating with increasing equilibrium line altitudes up to 3,000 to $3,100 \mathrm{~m}$ a.s.l. since the latest advance during 
Tab. 4: Equilibrium line altitudes (ELA) of glaciers in the Rieserferner-Ahrn Nature Park related to climatic conditions at the end of LIA (ca. "1850"), the present day situation (basis "2000") and compared with the scenario $+1.5 \mathrm{~K}$. Assuming that alpine summer temperature increases by $+1.5 \mathrm{~K}$, the ELA of glaciers rises by $230 \mathrm{~m}$ in the study area, based on a thermal gradient of $0.66^{\circ} \mathrm{C}$ per $100 \mathrm{~m}$ related.

Tab. 4: Mittlere Gleichgewichtslinie (ELA) auf Gletschern im Naturpark Rieserferner-Ahrn für Temperaturbedingungen zum Ende der „Kleinen Eiszeit“ (um „1850“), für aktuelle Bedingungen (um „2000") und für ein Temperaturszenario $+1.5 \mathrm{~K}$. Auf der Grundlage eines thermischen Gradienten von 0.66 C /100m ist bei Zunahme der Sommertemperatur um $1.5 \mathrm{~K}$ mit einem Anstieg der Gleichgewichtslinie um rund $230 \mathrm{~m}$ zu rechnen.

\begin{tabular}{|c|c|c|c|c|}
\hline Glacier area & ELA „, 1850“ [m] & ELA, rise [m] & ELA „,2000“ [m] & ELA +1.5 K [m] \\
\hline Rieserferner Mountains & 2747 & 99 & 2846 & 3077 \\
\hline Ahrntal Mountains & 2586 & 107 & 2693 & 2920 \\
\hline Study area, mean & 2667 & 105 & 2772 & 2999 \\
\hline
\end{tabular}

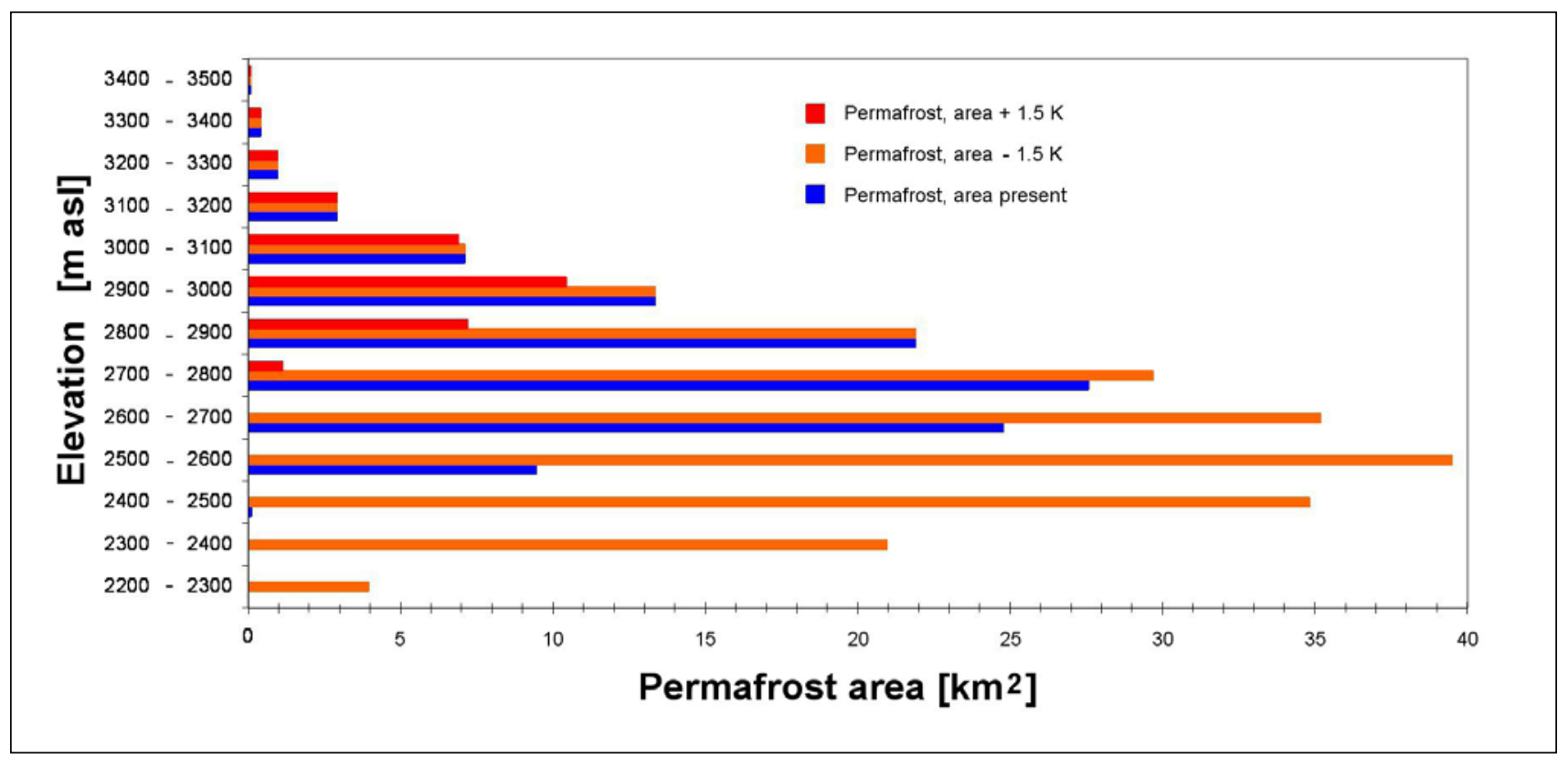

Fig. 7: Present-day extent of permafrost area in the Rieserferner-Ahrn Nature Park related to altitude and different thermal scenarios with lower (-1.5 K) and higher $(+1.5 \mathrm{~K})$ mean annual air temperature.

Abb. 7: Von Permafrost unterlagerte Flächen im Naturpark Rieserferner-Ahrn unter aktuellen Klimabedingungen sowie bei um $1.5 \mathrm{~K}$ höheren bzw. tieferen Temperaturen, differenziert nach Höhenstufen.

the 1970ies and 1980ies. Air temperature of the ablation period showed a rise of 0.3 to $0.5 \mathrm{~K}$ since 1981 and precipitation increased by $14 \%$, as data of the meteorological station Antholz-Mittertal (1236 m a.s.l.) indicate. Based on reports of glaciological survey (COMITATO Glaciologico ITALIANO 1977-2011), the development of the ablation area from about $<50 \%$ of the glacier surface at the end of the 1970s to about 20\% in 2010 (cf. SECCHIERI \& VALENTINI 1985, Autonome Provinz Bozen 2010, 2011) is connected with the rise of ELA of 150-300 m, which seems to be the principle reason of the latest glacier recession in the study area (cf. Escher-Vetter \& Siebers 2007).

Assuming the scenario of MATULLA et al. (2002) and MATULLA (2005) that forecast the increase of alpine summer temperature by $+1.5 \mathrm{~K}$ during the next 40 years, the ELA of glaciers can rise by $230 \mathrm{~m}$ in the study area (cf. chapter 3, tab. 4). Hence, numerous glaciers continue to retreat and can be affected by significant loss of volume and extent. The total glacier area decreases to $1.1 \mathrm{~km}^{2}$ in the Rieserferner Mountains and to $0.7 \mathrm{~km}^{2}$ in the upper Ahrntal Mountains.

\section{Development of permafrost distribution}

Different scenarios of the spatial variation of mountain permafrost in the Rieserferner-Ahrn Nature Park (DAMm \& LANGER 2006, DAMM 2008) are interrelated with lower (-1.5 $\mathrm{K})$ and higher $(+1.5 \mathrm{~K})$ MAAT compared to the present situation. The lower temperature represents the environmental situation before significant warming at the end of LIA, while the simulation with the higher temperature may describe possible future developments according to predicted climatic scenarios. The variability of the lower permafrost limit was calculated using a thermal gradient of $0.57 \mathrm{~K}$ per $100 \mathrm{~m}$ in the study area.

On the basis of field evidence and permafrost modelling, the present permafrost area in the Rieserferner-Ahrn Nature Park and that related to the thermal conditions at the end of LIA is calculated to be $109 \mathrm{~km}^{2}$ and $211 \mathrm{~km}^{2}$, respectively. Similarly, permafrost area would decrease by approximately $72 \%$ compared to present conditions with increasing MAAT of +1 to $+2 \mathrm{~K}$ (fig. 7). The permafrost areas calculated for the present conditions and different sce- 


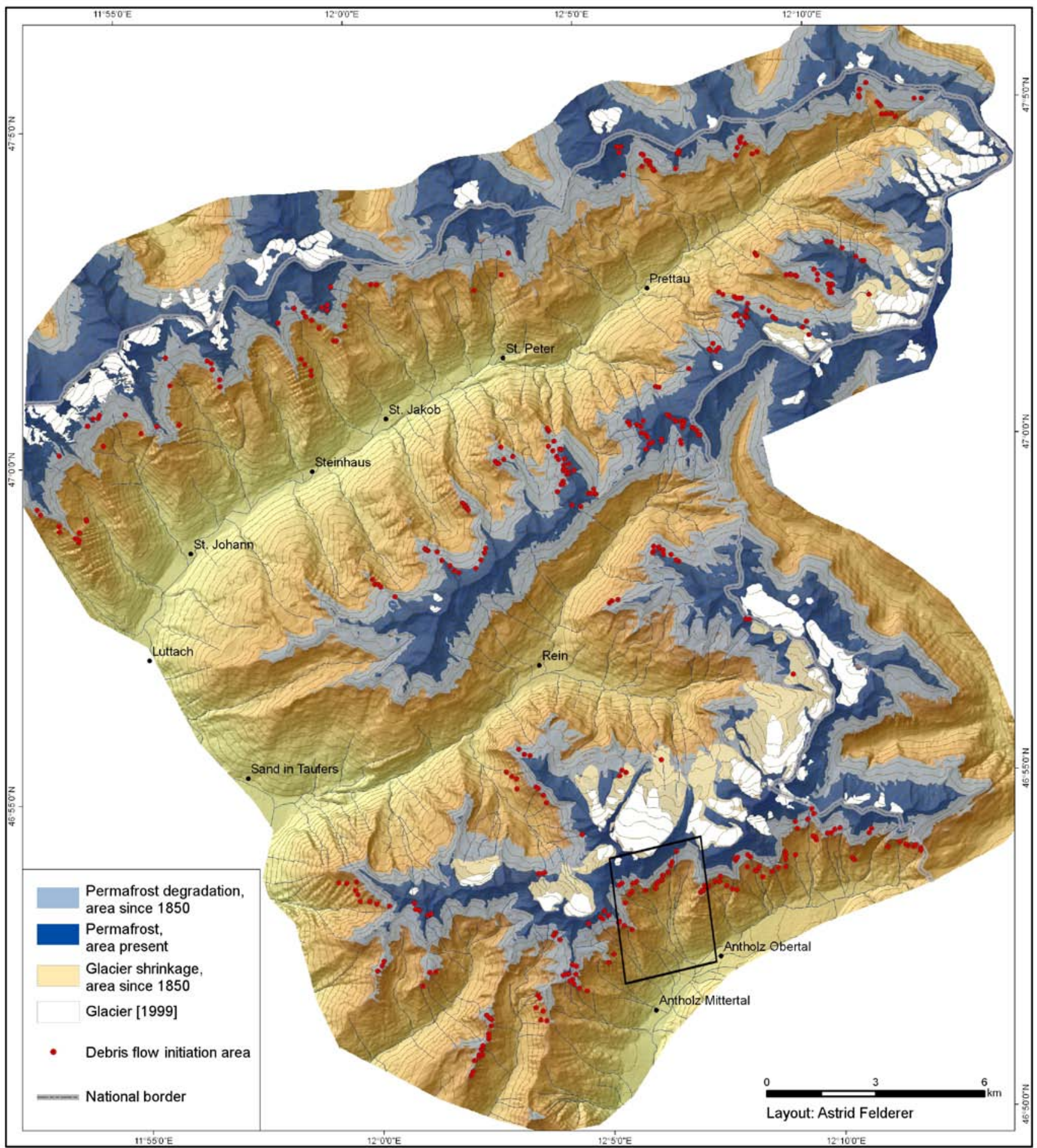

Fig. 8: General map of glacier extent, permafrost distribution and debris flow initiation areas in the Rieserferner-Ahrn Nature Park. In total, 408 debris flow initiation zones were mapped. The Klammbach drainage area is located in the south-eastern part of the study area (box).

Abb. 8: Gletscherflächen, Verbreitung von Permafrost und Lage von Muranrissen im Naturpark Rieserferner-Ahrn. Insgesamt konnten 408 Muranrisse kartiert werden. Das Einzugsgebiet des Klammbachs liegt im südöstlichen Teil des Untersuchungsgebiets (Kasten).

narios include all types of permafrost landforms and materials, such as loose rock, talus, rock glaciers and bedrock. Based on these assumptions present and future debris flow hazard potential is estimated as follows.

\subsection{Debris flow initiation zones and debris flow hazards}

Characterization and distribution of debris flow initiation zones

In total, 408 debris flow initiation zones were identified and mapped in the study area (fig. 8). In general, these zones occur throughout the study area and are concentrated in drainage basins of torrents and in various debris accumulations. Debris flow initiation zones are located to almost $50 \%$ in areas, where discontinuous permafrost degraded since the end of the LIA and to approximate $20 \%$ within the present area of probable permafrost. In contrast, only few detachment areas were identified in positions, where discontinuous permafrost is supposed to outlast the increase of temperature by $+1.5 \mathrm{~K}$. 

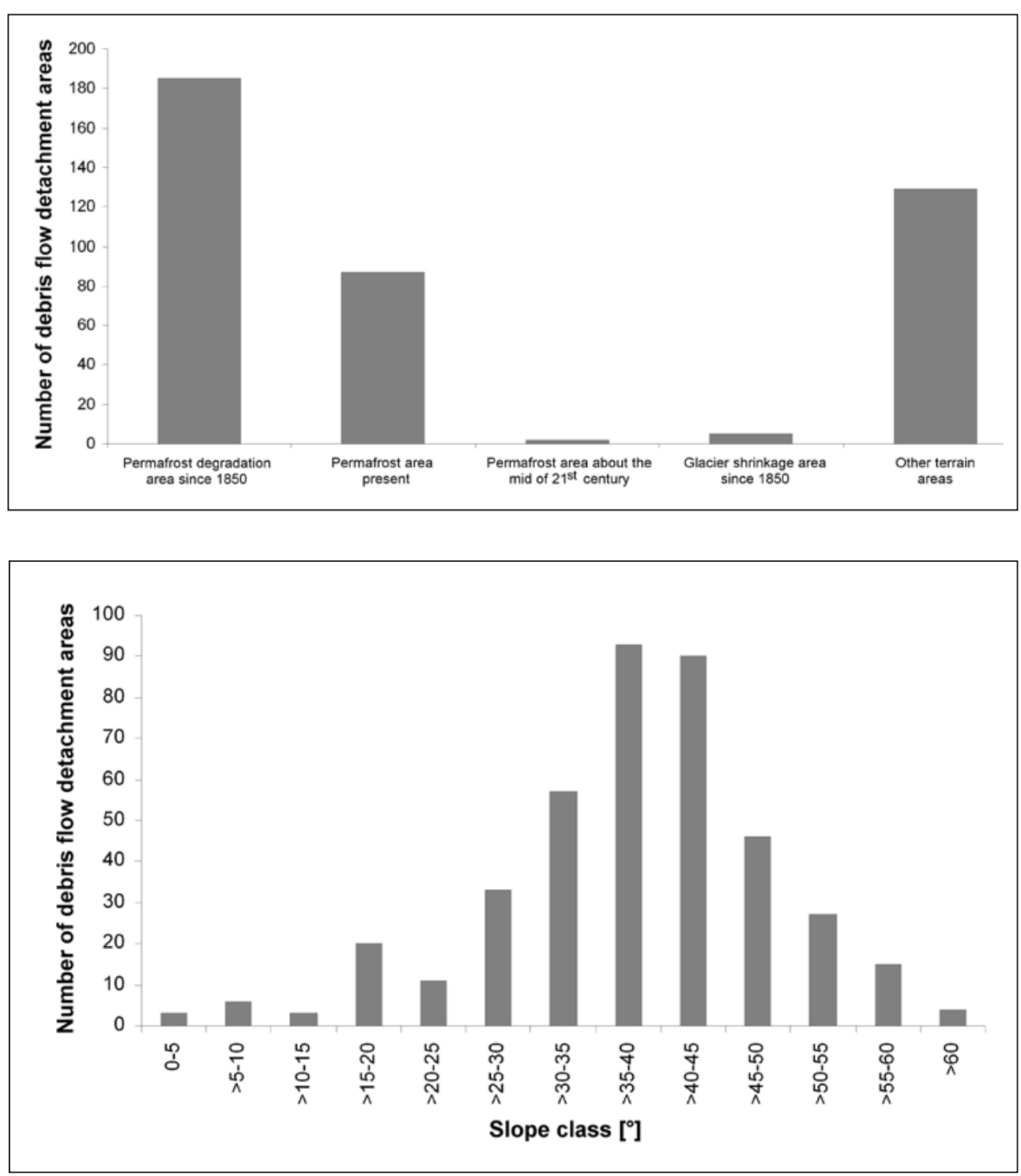

Fig. 9: Debris flow detachment areas in the Rieserferner-Ahrn Nature Park related to temporal variability of permafrost distribution and glacier extent.

Abb. 9: Häufigkeit von Muranrissen im Naturpark RieserfernerAhrn differenziert nach zeitlicher Variabilität von Permafrostverbreitung und Gletscherausdehnung.

Fig. 10: Debris flow initiation areas in the Rieserferner-Ahrn Nature Park related to slope gradient. Two thirds occur at slopes of more than $35^{\circ}$.

Abb. 10: Verteilung von Muranrissen im Naturpark RieserfernerAhrn differenziert nach der Geländeneigung. Zwei Drittel der Prozesse ereignen sich oberhalb von $35^{\circ}$.

Debris flow source areas in reference to altitude, surface characteristics and slope

Debris flow detachment areas occur between 1,800 and 3,000 $\mathrm{m}$ a.s.l. in the Rieserferner-Ahrn Nature Park. The major part of initiation areas is located in altitudes between 2,100 and 2,800 $\mathrm{m}$ a.s.l. with a maximum between 2,300 and 2,700 $\mathrm{m}$ a.s.l., which coincide with the distribution of present discontinuous permafrost calculated by DAMM \& LANGER (2006). Below 1,800 m a.s.l. close vegetation cover consisting of krummholz and forest as well as relief properties reduce the potential of debris flow sources.

Almost $47 \%$ of the mapped debris flows originated in loose rock, such as thick talus and till deposits, $37 \%$ in areas of alpine meadows and another $13 \%$ in shallow detritus covering bedrock (fig. 9). In general, source areas appear at slopes up to $66^{\circ}$ with a maximum occurrence between $35-40^{\circ}$ in the study area (fig. 10). Two thirds of these zones occurred at a slope steeper than $35^{\circ}$.

Permafrost degradation and stability of loose rock deposits The distribution of debris flow initiation zones coincides significantly with the spatial occurrence of unconsolidated debris in the study area. Thus, areas are susceptible to debris flow processes, where permafrost ice is degrading and talus or till deposits exist in (steep) slopes, where soil mechanical stability is just near the limit.

In general, present-day debris flows mainly originate from areas covered with loose rock, where vegetation cover is absent and where permafrost degraded since the end of the LIA. Corresponding sediments cover about $38 \mathrm{~km}^{2}$ and are uniformly distributed in the Rieserferner-Ahrn Nature Park. Furthermore, approximately $15 \mathrm{~km}^{2}$ (39\%) of the permafrost degradation area has a critical slope of $25-45^{\circ}$ (fig. 10) and is therefore susceptible to debris flow processes with increasing MAAT.

According to field evidence and GIS-based permafrost modelling, the total area of loose rock underlain by permafrost amounts to $21.7 \mathrm{~km}^{2}$ in the Rieserferner-Ahrn Nature Park (cf. DAMM \& LANGER 2006). Increasing permafrost degradation enhances instability of talus and till deposits and generates possible debris flow initiation areas in the future. According to topographic and environmental conditions of the study area the complete degradation of permafrost in areas of loose rock is expected due to a long-term increase of MAAT by $+1.5 \mathrm{~K}$. In such a scenario, permafrost in rock faces solely remains above $3,000 \mathrm{~m}$ a.s.l. and cover $1.8 \mathrm{~km}^{2}$. Overall, the area of debris sources and possible debris flow initiation zones increases to $20.1 \mathrm{~km}^{2}$ in the study area. 


\section{Discussion}

Climate variability mainly controls the cryosphere by changing air temperature and influences the mass balance of glaciers and the thickness and spatial extent of permafrost. As a consequence, glacier recession and permafrost degradation affect slope stability and enhance the susceptibility to mass movement and debris flow processes, as it is demonstrated in several studies (e.g. HAEBERLI 1999, HAEBERLI et al. 1999, Gruber et al. 2004, DAmm \& Felderer 2008).

In the context of debris flow processes, it is fundamental that permafrost degradation influences debris supply to talus and torrential systems, for instance by rock fall from destabilized rock walls and/or by permafrost creep processes (DAviEs et al. 2001, Gruber et al. 2004, DAmm 2007). In addition, the lowering of the permafrost table may increase the susceptibility of slopes for instabilities and consequently the initiation of debris flows. In this case, the thickening of the active layer can increase sediment availability in potential debris flow initiation zones and may also reduce the shear strength of debris (for this discussion see SATTLER et al. 2012).

The permafrost table acts as aquiclude and as potential failure plane during periods of elevated pore pressure, such as thaw periods or after strong summer rainfall (cf. LARSSON 1982). Laboratory experiments of RIsT (2007) showed that the active-layer instability was much stronger affected by the release of fine-grained material formerly fixed in the ice matrix than by the oversaturation of material at the base of the active layer. But for all, the most important factor seems to be the loss of internal ice in loose rock by permafrost melting, a process that was frequently observed in the study area (fig. 11, DAmm \& LANGER 2006, DAmm 2008, SANDmeier et al. 2012). The melting of interstitial ice leads to the loss of cohesion of previously frozen debris, which becomes available for mobilization by surface processes. The development of enhanced and irregular pore space and incomplete consolidation following permafrost thaw influences the hydraulic conductivity and reduces the overall mechanical slope stability (cf. ZiMMERMANN \& HAEBERLI 1992).

The hypothesized connection between permafrost degradation in non-creeping slope material and enhanced debris flow activity has not been proven yet, but observations of debris flows originating in areas presumed to be at the margin of contemporary permafrost distribution support this hypothesis (e.g. ZiMmERMANn and HAEBERLI 1992; StÖTter 1994; DAmm and Felderer 2008, Sattler et al. 2012). Furthermore, it is supposed that slopes currently underlain by degrading permafrost become less stable with ongoing climate change, even with increasing altitude (Harris et al. 2001, 2009, Stoffel \& Huggel 2012).

The cryosphere development in mountain regions has particular importance for issues of future research on climate impact (IPCC 2007a, 2007b). According to the „Special Report" of the IPCC from 2011 the number of cold days and nights will decrease, while the number of warm days and nights will increase in Europe (IPCC 2012). Corresponding changes are supposed to affect the alpine cryosphere directly by intensifying the continuous deglaciation and permafrost degradation.

In the present study the assessment of future natural hazard potential in the Rieserferner-Ahrn Nature Park is based

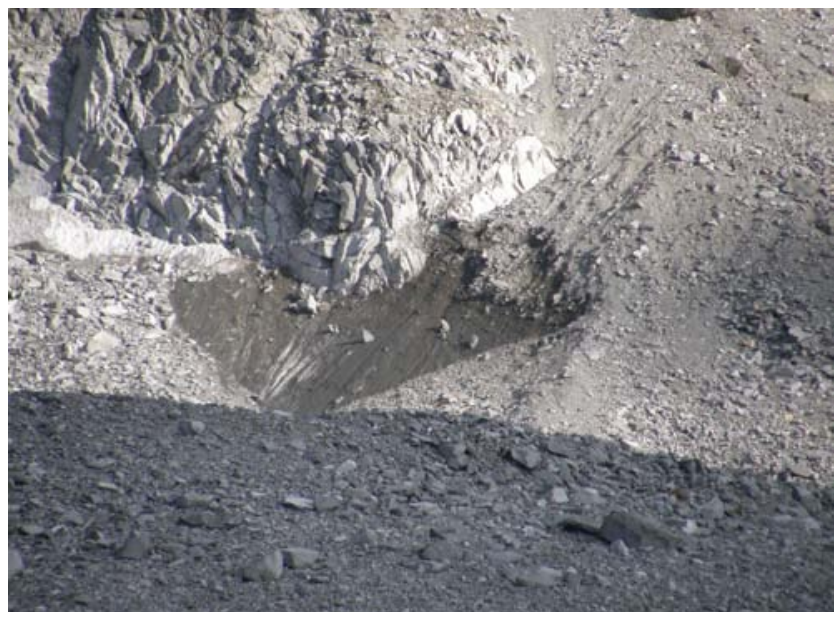

Fig. 11: Internal ice of talus and till deposits uncovered by sliding at the Hochgall peak north face in fuly 2011. Thickening of the seasonally unfrozen active layer and the loss of internal ice by permafrost degradation destabilize loose rock and favour the detachment of debris (photograph: B. Damm).

Abb. 11: Durch Rutschung freigelegtes Eis in Hangschutt- und Moränenablagerungen in der Nordflanke des Hochgalls im Juli 2011. Zunehmende Mächtigkeit der saisonalen Auftauschicht und tiefgreifende Permafrostdegradation destabilisieren Lockergesteine und begünstigen deren Abgleiten (Aufnahme: B. Damm).

on a scenario that forecasts an increase of air temperature by $1.5 \mathrm{~K}$ until the middle of the $21^{\text {st }}$ century. Even though the world climate report (IPCC 2007b) forecasts a global rise of mean air temperature by 1.1 to $6.4 \mathrm{~K}$ by the end of the $21^{\text {st }}$ century, in our study a more detailed differentiation seemed to be necessary for assessing climate impact. The climate change scenario assumes that the MAAT increases by $+2 \mathrm{~K}$ within the next 30 to 40 years in the Eastern Alps showing a pronounced warming during summer time with +2.5 K (cf. MAtulla 2005, OcCC 2007, Formayer et al. 2008). In this scenario, the mean annual precipitation hardly varies, while precipitation exhibits a significant seasonal variability. Overall, an increase of summer temperature (summer-JJAseason) by +1.5 to $+2.5 \mathrm{~K}$ and winter temperature (winterDJF-season) by +2 to $+3 \mathrm{~K}$ is assumed for the study area and the surroundings. Hence, this study is based on a restrained assessment for the degradation of cryosphere and the resulting natural hazard potential by using a moderate climatic scenario of $+1.5 \mathrm{~K}$.

The warming of the cryosphere in the study area exposed extended sources of destabilized debris in till deposits, creeping permafrost and talus during the past 150 years. Such sediments are susceptible to debris flow processes now. About $68 \%$ of the mapped debris flows originated in areas of destabilized debris. Furthermore, $74 \%$ of the detachment zones are located between 2,300 and 2,700 $\mathrm{m}$ a.s.l. Taking into account the climatic conditions of differing exposure this altitude range coincides with the present lower limit of permafrost in the Rieserferner-Ahrn Nature Park, which rose due to increased air temperature since the end of the LIA. In this perspective, the observable evidence of the recent past suggests a spatial expansion of the debris flow initiation area under warming conditions. In the Rieserferner-Ahrn Nature Park, the potential debris flow detachment area is calculated to increase by $52 \%$, if long-term MAAT rises by $+1.5 \mathrm{~K}$. 
Similarly to the results of our study, significant correlation between debris flow source areas and permafrost degradation areas were found amongst others by ZIMMERMANN \& HAEBERLi (1992) in the Swiss Alps and by STÖTTER et al. (2003, 2012) in the Suldental in northern Italy. In contrast, the case study of SATTLER et al. (2012) documents that distinct changes in the spatial position of debris flow initiation zones mainly occur at elevations above the current permafrost degrading areas in the Schnals valley (Ottztal Alps / Italy). The study was based on comparing debris flow activity since 1983 with modelled contemporary permafrost distribution. The authors conclude that the changes detected in debris flow activity were probably not influenced by atmospheric warming-induced permafrost degradation, but were connected with the thickening of the active layer. In accordance to the study of SATTLER et al. (2012), about $20 \%$ of debris flow detachment area in the Rieserferner-Ahrn Nature Park occurred above the simulated lower limit of permafrost. On the one hand, this may be due to uncertainties of the modelling of permafrost distribution. On the other hand, it seems to be probable that numerousness debris flows are related to the thickening of the seasonally unfrozen active layer and were triggered by increased ground-water circulation and pressure.

About $40 \%$ of debris flow detachment areas are located at slopes between $26-45^{\circ}$ in the Rieserferner-Ahrn Nature Park. Depending on lithologic characteristics slope inclinations like that are principally assumed to be susceptible to debris flow processes (e.g. JoHnson \& RAHN 1970, LEWIN \& WARBurton 1994). Thus, relevant terrain needs to be especially considered when assessing potential debris flow hazards, when permafrost continues to thaw with warming conditions.

The present study has tried to shed light on the effects of climate change on the high mountain cryosphere and the response of morphodynamics. With focus on the identification of present causalities and the prediction of potential future processes, the investigation has addressed the impacts of glacier recession and permafrost degradation on the spatial occurrence and distribution of debris flow initiation areas. Despite of the recent progress in climate impact research, the study illustrated that some questions have to be treated in greater detail, so as to bridge the gaps in knowledge, which still exist.

\section{Conclusions}

Atmospheric warming in high mountain environments causes a range of impacts, including glacier recession, reduction of permafrost extent and distribution as well as changes in thermal permafrost properties. Furthermore, it is likely that climate change affects the occurrence of natural hazards, like shallow landslides and debris flows, as their initiation is related to the degradation of the cryosphere. However, changes in mass movement activity can hardly be detected so far.

The present study indicates the importance of atmospheric warming for the occurrence and susceptibility of debris flow processes in the eastern Alps. There is first evidence that it is possible to quantify the regional debris flow hazard potential on the basis of field survey, in-situ measurements, climate data analyses, and GIS-based simulations for different climate scenarios and variable geomorphic stability.

The presented scenarios of the future distribution of instable areas susceptible to debris flow hazards are based on the assumption that MAAT increases by $1.5 \mathrm{~K}$ by the middle of the $21^{\text {st }}$ century. This may presumed to be a moderate increase of temperature in relation to the predicted climate development of the IPCC. The quantitative results of the present study can provide a basis for spatial planning and risk assessment.

\section{Acknowledgements}

The Autonomous Province of Bozen-South Tyrol supported the present study. The authors thank the Nature Parks Office for funding this research (Prot. Nr. 28.3.14.05/5399 /5270 16408) and the Hydrographic Office - Meteorological Service for providing climate data.

\section{References}

AMt FÜR WASSERSchutzBAuten (2005): ED-30 Datenbank Hochwasserund Murereignisse. Autonome Provinz Bozen Südtirol.

Autonome Provinz Bozen (2010): Glacier Report - Westlicher Rieserferner, Haushaltsjahr 2008/2009. - Hydrographisches Amt Bozen, Sonderdruck zum Climareport Nr. 179, Bozen.

Autonome Provinz Bozen (2011): Glacier Report - Westlicher Rieserferner, Haushaltsjahr 2009/2010. - Hydrographisches Amt Bozen, Sonderdruck zum Climareport Nr. 192, Bozen.

Arenson, L.U. (2003): Unstable Alpine Permafrost: a Potentially Important Natural Hazard - Variations of Geotechnical Behaviour with Time and Temperature. - Publications of the Institute for Geotechnical Engineering (IGT), 218: 4/03. Vdf Hochschul-Verlag der ETH, Zürich.

Beniston, M., Diaz, H.F. \& Bradley, R.S. (1997): Climate change at high elevation sites. An overview. - Climatic Change, 36(2): 233-251.

Böhm, R., Schöner, W., Auer, I., Hynek, B., Kroisleitner, C. \& Weyss, G. (2007): Gletscher im Klimawandel. Vom Eis der Polargebiete zum Goldbergkees in den Hohen Tauern. - Zentralanstalt für Meteorologie und Geodynamik (ZAMG), Wien.

Bonnet-Staub, J. (1999): Définition d'une typologie des dépôts de laves torentielles et identification de critères granulométriques et géotechniques concernant les zones sources. - Bulletin of Engineering Geology and the Environment, 57: 359-367.

Comitato Glaciologico Italiano (1977-2011): Relazioni della campagna glaciologica. - Geografia Fisica e Dinamica Quaternaria, 1-35.

Dамм, B. (1996): Gletscher-, Landschafts- und Klimaentwicklung in der Rieserfernergruppe (Tirol) seit dem Spätglazial. - Göttinger Geographische Abhandlungen, 104: 1-186.

DAмм, B. (1998): Der Ablauf des Gletscherrückzuges in der Rieserfernergruppe (Tirol) im Anschluss an den Hochstand um 1850. - Zeitschrift für Gletscherkunde und Glazialgeologie, 34: 141-159.

DAмм, B. (1999): L' evolutione dei ghiacciai, del paesaggio e del clima nei Monti di Tures (Alto Adige) dal Tardiglaciale. - Geografia Fisica e Dinamica Quaternaria, 22: 49-55.

Damm, B. (2005): Murereignisse am Klammbach im Antholzertal im Juli/ August 2005 - Ergebnisse der Feldbegehungen. Universität Göttingen, unveröffentlichter Bericht.

Dамм, B. (2007): Temporal Variations of Mountain Permafrost Creep in the Eastern European Alps derived from Rockglacier Monitoring. Quaternary International 167-168 (Supplement): 88-89.

Dамм, B (2008): Auswirkungen von Permafrostdegradation und Gletscherschwund im Naturpark Rieserferner-Ahrn. - Abschlussbericht, Autonome Provinz Bozen (unpublished).

Damm, B. \& LANGer, M. (2006): Kartierung und Regionalisierung von Permafrostindikatoren im Rieserfernergebiet (Südtirol/Osttirol). - Mitteilungen der Österreichischen Geographischen Gesellschaft, 148: 295-314.

DAmm, B. \& Felderer, A. (2008): Identifikation und Abschätzung von Murprozessen als Folge von Gletscherrückgang und Permafrostdegradation im Naturpark Rieserferner-Ahrn (Südtirol). - Abhandlungen der Geologischen Bundesanstalt, 62: 29-32. 
Damm, B., Pröbstl, U. \& Felderer, A. (2012): Perception and Impact of Nat ural Hazards as Consequence of Warming of the Cryosphere in Tourism Destinations. A Case Study in the Tux Valley, Zillertaler Alps, Austria. - Interpraevent, 12: 90-91.

Davies, M.C.R., Hamza, O. \& Harris, C. (2001): The Effect of Rise in Mean Annual Temperature on the Stability of Rock Slopes Containing IceFilled Discontinuities. - Permafrost and Periglacial Processes, 12: 137144

DIN 18123 (1996): Baugrund, Untersuchung von Bodenproben. Bestimmung der Korngrößenverteilung, Normenausschuß Bauwesen im DIN Deutsches Institut für Normung e.V., Berlin.

Escher-Vetter, H. \& Siebers, M. (2007): Sensitivity of glacier runoff to summer snowfall events. - Annals of Glaciology, 46: 309-315

Fischer, L., KäÄв, A., Huggel, C. \& Noetzli, J. (2006): Geology, glacier retreat and permafrost degradation as controlling factors of slope instabilities in a high-mountain rock wall: the Monte Rosa east face. - Natural Hazards and Earth System Sciences, 6: 761-772.

Formayer, H., Clementschitsch, L., Kromp-Kolb, H. (2008): Regionale Klimaänderung in Österreich. Global2000 Umweltforschungsinstitut (http://www.global2000.at./files/klimawandel_oesterreich.pdf).

Furrer, G. \& Fitze, P. (1970): Beitrag zum Permafrostproblem in den Alpen. - Vierteljahrsschrift der Naturforschenden Gesellschaft Zürich, 115: 353-368.

Gruber, S., Hoelzle, M. \& Haeberli, W. (2004): Permafrost thaw and destabilization of Alpine rock walls in the hot summer of 2003. - Geophysical Research Letters, 31: L13504.

Haeberli, W. (1973): Die Basis-Temperatur der winterlichen Schneedecke als möglicher Indikator für die Verbreitung von Permafrost in den $\mathrm{Al}-$ pen. - Zeitschrift für Gletscherkunde und Glazialgeologie, 9: 221-227.

Haeberli, W. (1990): Permafrost. Internationale Fachtagung über Schnee, Eis und Wasser der Alpen in einer wärmeren Atmosphäre. - Mitteilungen der Versuchsanstalt für Wasserbau, Hydrologie und Glaziologie, ETH Zürich, 108: 71-88.

Haeberli, W. (1992): Possible effects of climate change on the evolution of Alpine Permafrost. - Catena Supplement, 22: 23-35.

HAEBERLI, W. (1999): Hangstabilitätsprobleme im Zusammenhang mit Gletscherschwund und Permafrostdegradation im Hochgebirge. - Relief, Boden, Paläoklima, 14: 11-30.

Haeberli, W., KäÄв, A., Hölzle, M., Bösch, H., Funk, M., Vonder Mühll, D. \& Keller, F. (1999): Eisschwund und Naturkatastrophen im Hochgebirge. - Vdf Hochschul-Verlag ETH Zürich.

HAeberLi, W. \& GRUber, S. (2009): Global warming and mountain permafrost. In: Margesin, R. (Ed): Permafrost Soils. - Soil Biology, 16: 205-218.

HARrIs, C. (2005): Climate change, mountain permafrost degradation and geotechnical hazard. - In: Huber, U., Bugmann, H. \& Reasoner M. (Eds): Global Change and Mountain Regions. - Advances in Global Change Research V. 23, Dordrecht (Springer), 215-224.

Harris, C., Davies, M. \& Etzelmüller, B. (2001): The assessment of potential geotechnical hazards associated with mountain permafrost in a warming global climate. - Permafrost and Periglacial Processes, 12: $145-156$.

Harris, C., Vonder Mühll, D., Isaksen, K., Haeberli, W., Sollid, J.L., King, L., Holmlund, P., Dramis, F., Guglielmin, M. \& Palacios, D. (2003): Warming Permafrost in European Mountains. - Global and Planetary Change, 39: 215-225.

Harris, C., Arenson, L.U., Christiansen, H.H., Etzelmüller, B., Frauenfelder, R., Gruber, S., Haeberli, W., Hauck, C., Hölzle, M., Humlum, O., Isaksen, K., KäÄB, A., Kern-Lutschg, M.A., Lehning, M., Matsuoka, N., Murton, J.B., Noetzli, J., Phillips, M., Ross, N., Seppala, M., Springman, S.M. \& Vonder Muehll, D.V. (2009): Permafrost and climate in Europe: Monitoring and modelling thermal, geomorphological and geotechnical responses. - Earth-Science Reviews, 92: 117-171.

IPCC (2007a): Climate Change 2007: The Scientific Basis. Summary for Policymakers, Cambridge. www.ipcc.ch (12.12.07).

IPCC (2007b): Climate Change 2007: Synthesis Report. http://www.ipcc.ch/ publications/.

IPCC (2012): Managing the risks of extreme events and disasters to advance climate change adaption. http://ipcc-wg2.gov/SREX/.

Ishikawa, M. \& Hirakawa, K. (2000): Mountain Permafrost Distribution Based on BTS Measurements and DC Resistivity Soundings in the Daisetsu Mountains, Hokkaido, Japan. - Permafrost and Periglacial Processes, 11: 109-123.

Iverson, R.M. (2005): Debris-flow mechanics. In: Jakoв, M. ש Hungr, O. (Eds.): Debris-flow Hazards and Related Phenomena. Springer, Berlin, $105-134$
Johnson, A.M. \& RAHn, P.H. (1970): Mobilization of debris flows. Zeitschrift für Geomorphologie N.F, Suppl.-Bd., 9:168-186.

Keiler, M., Knight, J. \& Harrison, S. (2010): Climate change and geomorphological hazards in the eastern European Alps. - Philosophical Transactions of the Royal Society - Mathematical Physical and Engineering Sciences, 368(1919): 2461-2479.

Kneisel, C., Rothenbühler, C., Keller, F. \& Haeberli, W. (2007): Hazard assessment of potential periglacial debris flows based on GIS-based spatial modelling and geophysical field surveys: a case study in the Swiss Alps. - Permafrost and Periglacial Processes, 18: 259-268.

Kunn, M. (1990): Energieaustausch Atmosphäre - Schnee und Eis. - Int Facht. Schnee, Eis u. Wasser der Alpen in einer wärmeren Atmosphäre. - Mitteilungen VAW, ETH Zürich, 108: 21-32.

LAmbrecht, A. \& KuHn, M. (2007): Glacier changes in the Austrian Alps during the last three decades, derived from the new glacier inventory. - Annals of Glaciology, 46: 177-184.

LANGER, M. \& DAMM, B. (2008): CRYOSNOW - An approach for mapping and simulation of mountain permafrost distribution based on the spatial analyses of perennial snow patches. - Geophysical Research Abstracts 10 (http://meetings.copernicus.org/www.cosis.net/abstracts/ EGU2008/11263/EGU2008-A-11263.pdf.)

LARSSON, S. (1982): Geomorphological effects on the slopes of Longyear Valley, Spitsbergen, after a heavy rainstorm in July 1972. - Geografiska Annaler, Series A Physical Geography, 64: 105-125.

Lewin, J. \& Warburton, J. (1994): Debris flow in an alpine environment - Geog. J. Geog. Assoc. 343, 79(2): 98-107.

Lewkowicz, A. \& EdNie, M. (2004): Probability Mapping of Mountain Permafrost Using the BTS Method, Wolf Creek, Yukon Territory, Canada. - Permafrost and Periglacial Processes, 15: 67-80.

Mair, V., Lang, K., Tagnin, S., Zischg, A., Krainer, K., Stötter, J., Zilger, J., Belitz, K., Schenk, A., DAmm, B., Kleindienst, H., BuchER, K. \& MunARI, M (2008): PROALP - Rilevamento e Monitoraggio dei Fenomeni Permafrost. - Neve e Valanghe, 64: 50-59.

Matulla, C. (2005): Regional, seasonal and predictor-optimized downscaling to provide groups of local scale scenarios in the complex structured terrain of Austria. - Meteorologische Zeitschrift, 14/1: 31-47.

Matulla, C., Groll, N., Kromp-Kolb, H., Scheifinger, H., Lexer, M.J. \& Widmann, M. (2002): Climate change scenarios at Austrian National Forest Inventory sites. - Climate Research, 22: 161-173.

OcCC (2007): Climate Change and Switzerland 2050 - Expected Impacts on Environment, Society and Economy. - OcCC - Organe consultatif sur les changements climatiques (Swiss Academy of Sciences), http:// proclimweb.scnat.ch/portal/ressources/794.pdf.

Patzelt, G. \& Aellen, M. (1990): Gletscher. - Int. Facht. Schnee, Eis u Wasser der Alpen in einer wärmeren Atmosphäre. - Mitteilungen VAW, ETH Zürich, 108: 49-70.

PröBstl, U. \& DAmм, B. (2009): Perception and evaluation of natural hazards as a consequence of glacier retreat and permafrost degradation in tourism destinations - a case study in the Tux Valley (Zillertaler Alps, Austria). In: Kromp-Kolb, H. \& Schwarzl, I. (Eds.) StartClim 2008 „Adaption to Climate Change in Austria“, BOKU, Vienna, 23-24 and $38-41$.

Remaître, A., Malet, J.P. \& Maquaire, O. (2005): Morphology and sedimentology of a complex debris flow in a clay-shale basin. - Earth Surface Processes and Landforms 30: 339-348.

Rist, A. (2007); Hydrothermal processes within the active layer above alpine permafrost in steep scree slopes and their influence on slope stability. - Universität Zürich, Schriftenreihe Physische Geographie, Volume 57.

RösEn, P. (2005): Die rezente Gletscherentwicklung im oberen Ahrntal (Prettau/Südtirol). - Diploma thesis, University of Göttingen.

Rolshoven, M. (1982): Alpines Permafrostmilieu in der Lasörlinggruppe/ Nördliche Deferegger Alpen (Osttirol). - Polarforschung, 52: 55-64.

Sandmeier, C., Damm, B. \& Terhorst, B. (2012): Murgangpotential eines alpinen Einzugsgebietes im Antholzer Tal (Südtirol). - Interpraevent 12/1: 339-350.

SAttler, K., Keiler, M., Zischg, A. \& Schrott, L. (2011): On the Connection between Debris Flow Activity and Permafrost Degradation: A Case Study from the Schnalstal, South Tyrolean Alps, Italy. - Permafrost and Periglacial Processes, 22: 254-265.

Secchieri, F. \& VAlentini, P. (1985): Indagine glaciologica sulla Vedretta Alta e sulla Vedretta Occidentale di Ries (Alto Adige). - Geografia Fisica e Dinamica Quaternaria, 8: 137-143.

Stötter, J., Fuchs, S., KeIler, M. \& Zischg, A. (2003): Oberes Suldental. Eine Hochgebirgsregion im Zeichen des Klimawandels. - Innsbrucker Geographische Studien, 33/3: 239-281. 
Stötter, J., Zischg, A. \& SAiler, R. (2012): Entwicklung des Permafrostes in Südtirol. - Innsbrucker Geographische Studien, 39: 45-66.

Stoffel, M. \& HugGel, C. (2012): Effects of climate change on mass movements in mountain environments. - Progress in Physical Geography, 36: 421-439.

Vonder Muehll, D., Noetzli, J., Roer, I., Makowski, K. ひ Delaloye, R. (2007): Permafrost in Switzerland 2002/2003 and 2003/2004. - Glaciological Report (Permafrost) No. 4/5 of the Cryospheric Commission (CC) of the Swiss Academy of Sciences (SCNAT) and Department of Geography, University of Zurich.

WINKLER, S. (2009): Gletscher und ihre Landschaften - eine illustrierte Einführung. - WBG Darmstadt.

Winkler, S., Chinn, T., Gärtner-Roer, I., Nussbaumer, S.U., Zemp, M. d ZuмвÜнL, H.J. (2010): An introduction to mountain glaciers as climate indicators with spatial and temporal diversity. - Erdkunde 64: 97-118.

Zanvettor, G., Colmano, D. \& Iellici, M. (2006): Landeskartographie und Geographisches Informationssystem - Beschreibung der Kartographischen Daten. - Autonome Provinz Bozen-Südtirol, Amt für überörtliche Raumordnung.

Zemp, M., Haeberli, W., Hoelzle, M., \& Paul, F. (2006): Alpine glaciers to disappear within decades? - Geophysical Research Letters, 33: L13504.

Zemp, M., Paul, F., Hoelzle, M. \& Haeberli, W. (2007): Glacier fluctuations in the European Alps 1850-2000: an overview and spatio-temporal analysis of available data. - In: OrLove, B., WIEGANDT, E. \& Luckman, B. (Eds.): The darkening peaks: Glacial retreat in scientific and social context: 152-167, University of California Press.

Zimmermann, M. \& Haeberli, W. (1992): Climatic change and debris flow activity in high mountain areas; a case study in the Swiss Alps. - Catena Supplement, 22: 59-72.

Zimmermann, M., Mani, P., Gamma, P., Gsteiger, P., Heiniger, O. ひ HunZiKeR, G. (1997): Murganggefahr und Klimaänderung - ein GISbasierter Ansatz. - Schlussbericht NFP31, Vdf Hochschulverlag an der ETH Zürich, $161 \mathrm{pp}$.

Zischg, A., Macconi, P., Pollinger, R., Sperling, M., Mazzorana, B. Marangoni, N., Berger, E. \& Staffler, H. (2007): Historische Überschwemmungs- und Murgangereignisse in Südtirol. Erhebung und Dokumentation. - Der Schlern, 81/3: 3-16.

Zischg, A., Mair, V., Tonidandel, D. \& Lang, K. (2012): Berücksichtigung von Permafrost in der Gefahrenzonenplanung in Südtirol. Innsbrucker Geographische Studien, 39: 173-187.

ZnAmensky, D. \& Gramani, M. (2000): Debris-flow grain-size analysis. In: WieczoreK, G. \& NAeser, N. (Eds.): Debris-Flow Hazards Mitigation: Mechanics, Prediction, and Assessment. Balkema, Rotterdam, $537-545$. 